\title{
Bacterial growth and tidal variation in bacterial abundance in the Great Sippewissett Salt Marsh
}

\author{
David Kirchman ${ }^{1 *}$, Bruce Peterson ${ }^{2}$ and David Juers ${ }^{2}$ \\ 1 Division of Applied Sciences, Harvard University, Cambridge, Massachusetts 02138, USA \\ 2 Ecosystems Center, Marine Biological Laboratory, Woods Hole, Massachusetts 02543, USA
}

\begin{abstract}
Bacterial abundance was measured monthly during 2 consecutive tidal cycles in the main channel of the Great Sippewissett Salt Marsh. It was consistently highest in low tide waters and lowest in water flooding the marsh from Buzzards Bay. Absolute tidal variation in bacterial abundance was lower in winter than in summer. However, relative variation (logarithm of bacterial abundance vs. time) was approximately the same throughout the year. We hypothesize that most of the tidal variation in bacterial abundance was due to conservative mixing, but that the bacteria-rich water sampled at low tide was the result of bacterial growth. In August bacterial growth rates were estimated from changes in bacterial abundance in water samples in which the particles were diluted 10-fold. Bacteria appear to grow fast enough to account for the difference in bacterial abundance between low and high tide. In spite of the large difference in bacterial abundance in low vs. high tide samples, there was no significant net export of bacteria from Great Sippewissett into Buzzards Bay during the year. Our estimates of bacterial growth rates and biomass were also used to calculate the contribution of bacteria to the carbon cycle of the marsh. Bacterial production was small compared to net primary production in the marsh and did not appear to contribute significantly $(<10 \%)$ to the carbon required by the large mussel population in Great Sippewissett.
\end{abstract}

\section{INTRODUCTION}

Streams and channels of salt marsh estuaries serve as links between marsh and adjacent coastal waters. Dissolved organic compounds (DOC), inorganic nutrients, particulate detritus and planktonic organisms are potentially exchanged via these conduits flushed by the tides. Planktonic bacteria may utilize the dissolved compounds and particulate detritus in streams and channels and thereby affect the flux of materials between salt marsh and coastal waters. In addition, bacterial biomass produced in marsh waters may be a food source for grazers in the marsh or in coastal waters if the bacteria are exported out of the marsh.

Rates of bacterial production have been used in coastal waters to estimate how much carbon is processed by bacteria (see review by Azam et al., 1983). In coastal waters bacteria appear to utilize a large proportion (10 to $50 \%$ ) of primary production. In the single published study of bacterial production in a salt marsh,

\footnotetext{
- Present address: Department of Microbiology, University of Georgia, Athens, Georgia 30602, USA
}

Wright and Coffin (1984) estimated that the bacteria utilized 300 to $400 \mu \mathrm{g} \mathrm{C} \mathrm{l}^{-1} \mathrm{~d}^{-1}$. This rate is among the highest reported for marine environments (see review by Ducklow, 1983), although it is not clear how much of marsh production is processed by planktonic bacteria. Rates of bacterial production have also been used in coastal waters to estimate how much bacterial biomass is passed on to higher trophic levels. This calculation is possible in coastal waters, since bacterial biomass is relatively constant over time (Ducklow and Kirchman, 1983), implying that bacterial production is balanced by grazing (reviewed by Azam et al., 1983). In coastal waters microflagellates are thought to be the principle grazers of bacteria (Azam et al., 1983). The fate of bacteria in marsh water is more complex. In addition to possible planktonic grazers, large invertebrates may also be important bacteriovores. Wright et al. (1982) demonstrated that bacterioplankton can be a food source for the mussel Geukensia demissa. Furthermore, bacterial biomass varies greatly in salt marshes (see below). This suggests that bacterial production may not always be balanced by grazing, although Wright and Coffin (1984) found that grazing 
and production were nearly equal in the estuary they examined.

The spatial distribution of bacteria in estuaries can be quite complex and is in part due to the physical mixing of water masses. In a study of a salt marsh estuary in North Carolina, Palumbo and Ferguson (1978) concluded that the upper portion of the estuary, which had high bacterial abundance, was a source of bacteria. The bacteria-rich water mass mixed conservatively with coastal seawater, which had low bacterial abundance. Palumbo and Ferguson (1978) observed a negative, linear relation between number of bacteria and chlorinity. In North Inlet Marsh, Wilson and Stevenson (1980) found that bacterial abundance decreased in a transect from the high marsh to the open ocean. In contrast, Wright and Coffin (1983) reported that bacterial abundance was highest downstream from the uppermost region of three estuaries in Massachusetts. There was a peak of bacterial abundance at moderate salinity rather than a simple, negative linear relation between bacterial abundance and salinity.

The temporal variation in bacterial abundance in marsh water is also large. According to Wright and Coffin (1983), over a year the number of bacteria varied 10 -fold in the Essex River estuary but only 4 -fold in adjacent coastal waters of Massachusetts. Diel variation in bacterial abundance is due in part to the physical mixing generated by the tides. In the Essex River estuary studied by Wright and Coffin (1983), bacterioplankton abundance was highest at low tide in the lower portion of the estuary; in the upper portion bacterial abundance was highest at high tide. Wilson and Stevenson (1980) found no significant change over a tidal cycle in total bacterial abundance but did observe a significant fluctuation in the abundance of the bacteria attached to particles, which appeared to be due to the resuspension of sediment particles. The sediments also could be the source of unattached bacteria and thus contribute to the tidal fluctuation in unattached bacteria. However, Rublee et al. (1983) established that bacteria were tightly bound to sediment particles and were not easily removed by the flooding of high salinity water.

We measured total bacterial abundance in the Great Sippewissett Salt Marsh in order to examine how and by what mechanism bacterial abundance varied over a tidal cycle. We examined the hypothesis that the high numbers of bacteria sampled in marsh water were the result of bacterial growth in the water column, rather than from resuspension of sediments. Data on bacterial biomass and bacterial production were also used to evaluate the contribution of bacteria to the carbon cycle of the marsh and the export of bacterial biomass to adjacent coastal waters.

\section{MATERIALS AND METHODS}

Study site and sample collection. Great Sippewissett Salt Marsh is located on Cape Cod, Massachusetts, USA. The marsh has been intensively studied (see Valielia and Teal, 1979), and recently Peterson et al. (1982) described the tidal exchange of reduced sulfur compounds. The data discussed in this paper were collected concurrently with those of Peterson et al. (1982). The area of the marsh is about 50 ha of which $44 \%$ is covered with Spartina alterniflora and $18 \%$ with $S$. patens. Muddy and sandy bottom creeks comprise $35 \%$ of the marsh; the remaining area $(3 \%)$ is covered with pans and algal mats. We examined bacterial abundance in the channel (40 $\mathrm{m}$ in width) through which water from Buzzards Bay floods and drains the marsh (Fig. 1). Samples for bacterial abundance were

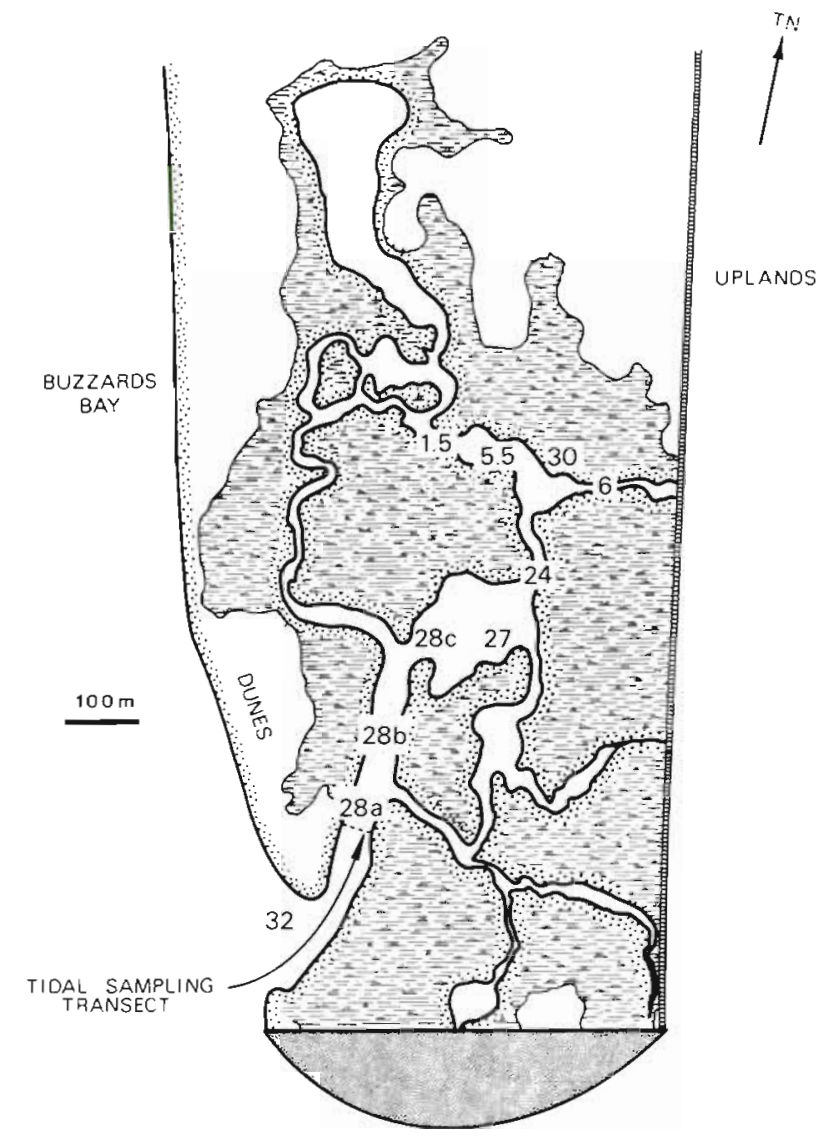

Fig. 1. Study area in Great Sippewissett Salt Marsh. Numerals are salinity measurements taken in a transect at low tide in July 1980 (see Fig. 5 and text)

collected at this channel hourly for 2 consecutive tidal cycles and $20 \mathrm{ml}$ subsamples preserved immediately in formaldehyde (final concentration of $2 \%$ ); they were refrigerated in scintillation vials until the bacteria were counted.

Samples for the determination of chlorinity were 
collected concurrently as described in detail by Peterson et al. (1982). Chlorinity was measured in filtered water using a salinometer. In addition, salinity was measured with a hand-held refractometer (American Optical) when a transect of the marsh was taken. Samples for bacterial abundance along this transect were preserved as described above. The salinity (\%o) and location where these samples were taken can be seen in Fig. 1.

Bacterial abundance. Total abundance of bacteria was determined by the acridine orange direct count method (Hobbie et al., 1977). In August 1980, average cell size of bacteria was estimated from photomicrographs of acridine orange-stained cells; 25 bacteria were measured per sample. Bacterial carbon was calculated by multiplying the average cell size by $1.21 \times$

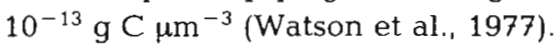

The abundance of particle-bound bacteria was estimated by counting the number of particles per field and the number of bacteria per particle. Two filters were prepared for each subsample and at least 10 fields were examined per filter to determine the average number of particles per field. At least 10 particles per filter were examined to determine the number of bacteria per particle. The data were not corrected for those bacteria, which cannot be counted, underneath or inside particles. Kirchman and Mitchell (1982) estimated this error to be $45 \%$ of the attached bacterial abundance.

Bacterial growth. Bacterial growth rates were estimated by measuring the increase in abundance during short incubations in treated water samples. Water was collected with a polycarbonate bottle from the marsh at low tide or from Buzzards Bay near the mouth of the marsh, and was filter-sterilized. The water was first filtered through precombusted glass fiber filters (Whatman GF/C) under low vacuum (less than $100 \mathrm{~mm}$ of mercury) in order to minimize breakage of phytoplankton cells and other large particles. The filtrate was then filtered through Millipore filters with a nominal pore size of $0.22 \mu \mathrm{m}$. The first $10 \mathrm{ml}$ of this filtrate was discarded in order to minimize contamination by compounds leached from the filter.

Thirty $\mathrm{ml}$ of unfiltered inocula from the bay or marsh were added to the filter-sterilized water in $300 \mathrm{ml}$ BOD bottles such that the final dilution of the inocula was $1: 10$. The glass bottles were oven-sterilized at $500^{\circ} \mathrm{C}$ for $4 \mathrm{~h}$ before being used in these experiments. Once filled, the bottles were incubated in the channel (1979) or in the laboratory at the temperature of the marsh water (1980). At various times $10 \mathrm{ml}$ subsamples were withdrawn and preserved for subsequent determination of bacterial abundance.

Bacterial growth rates were calculated using the approach of Kirchman et al. (1982) to analyze the increase in bacterial abundance over time. This approach assumes that a proportion of the bacterial population is not dividing while the growing bacteria are dividing at a constant specific growth rate. The increase in bacterial abundance over time can be described by $\quad \mathrm{N}(\mathrm{t})=\mathrm{N}_{\mathrm{a}}(0) \mathrm{e}^{\mu \mathrm{t}}+\mathrm{D}$

where $N(t)=$ total number of bacteria; $N_{a}(0)=$ number of bacteria at $\mathrm{t}=0$ dividing at a specific growth rate $\mu_{;} \mathrm{D}=$ number of non-dividing bacteria. The direct count method cannot distinguish non-dividing from dividing cells. Even so, the proportion of dividing cells can be estimated by fitting data to the equation given above.

Tidal exchange of bacteria. The possible export of bacteria from Great Sippewissett to Buzzard Bay was examined by computing the exchange of bacteria over the tidal cycles. The tidal exchange was calculated by multiplying the bacterial density (cells $\mathrm{m}^{-3}$ ) by the volume of water flooding or ebbing from the marsh. Total import to the marsh from the bay and total export from the marsh to the bay were calculated by summing the exchange over flooding and ebbing tides, respectively. Net exchange or transport of bacteria per tidal cycle was calculated by subtracting the import from export flux. Peterson et al. (1982) describe in detail the tidal water balance.

\section{RESULTS}

\section{Total bacterial abundance during tidal cycles}

Total bacterial abundance varied greatly over the tidal cycle (Fig. 2). The maximum abundance of bac-

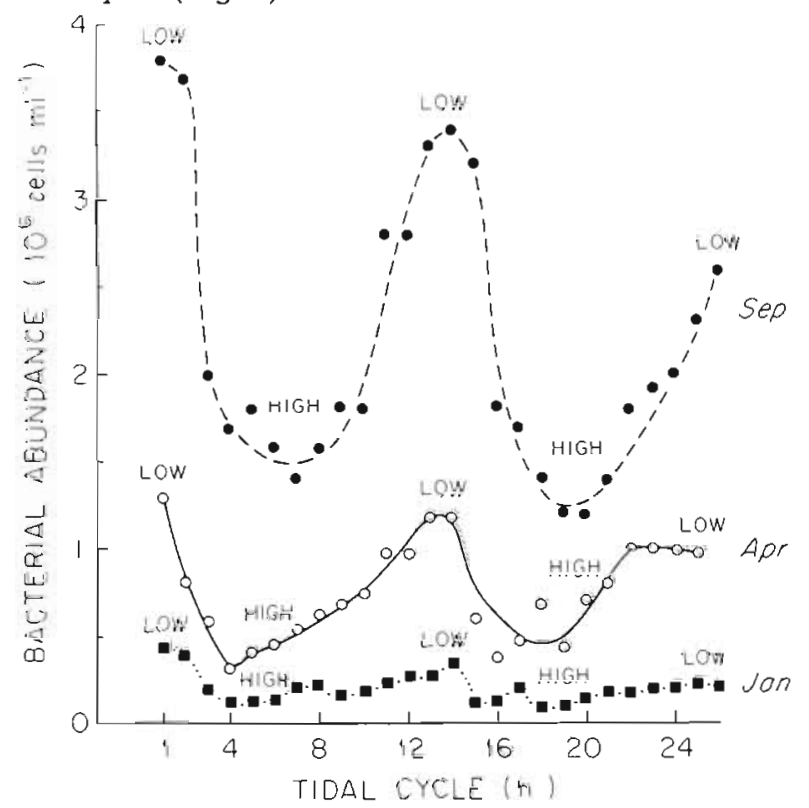

Fig. 2. Bacterial abundance in Great Sippewissett Marsh over 2 consecutive tides during Jan, Apr and Sep. The first sample of each tidal cycle was taken at 1400 (Jan), 1700 (Apr) and 1400 (Sep) 


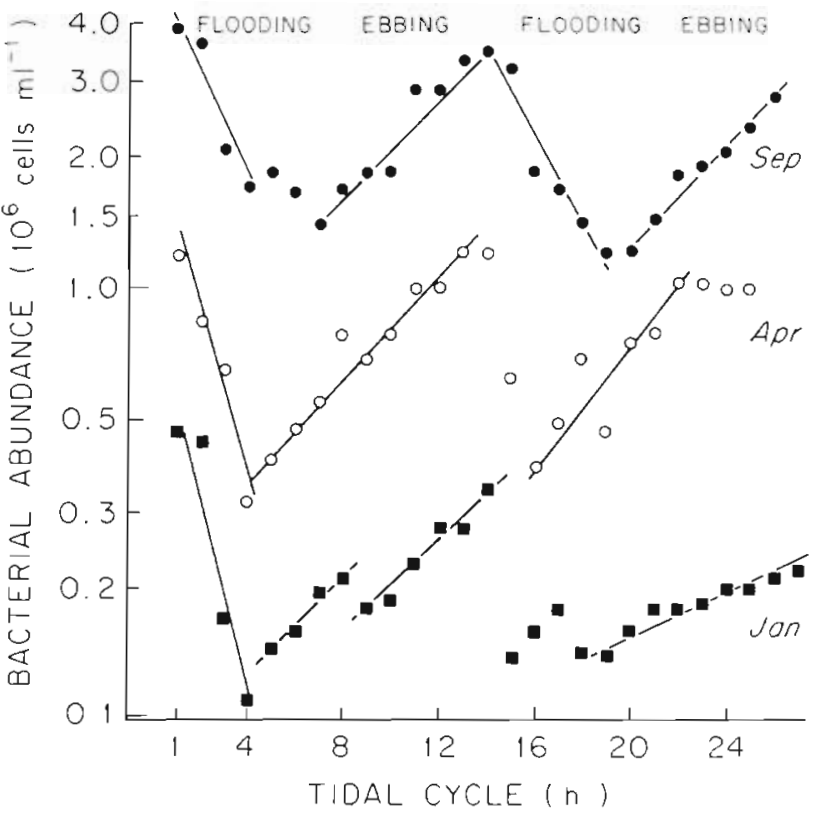

Fig. 3. Bacterial abundance in Great Sippewissett Marsh over 2 consecutive tides during Jan, Apr and Sep. Data plotted on logarithmic scale; in Fig. 2 on arithmetic scale. Tables 3 and 4 give statistical analyses of the data from these $3 \mathrm{mo}$ and of the remaining months not graphed

teria unattached to particles was at low tide, the minimum at high tide. Absolute tidal variation in abundance was greater in summer than in winter. For example, in September bacterial abundance varied from $1.4 \times 10^{6}$ cell ml ${ }^{-1}$ at high tide to $3.8 \times 10^{6}$ cells $\mathrm{ml}^{-1}$ at low tide; whereas, in January abundance varied from $0.12 \times 10^{6}$ cells $\mathrm{ml}^{-1}$ at high tide to $0.34 \times$ $10^{6}$ cells $\mathrm{ml}^{-1}$ at low tide. However, when graphs of $\mathrm{ln}$ (bacterial abundance) vs. time are examined, the variation over the tidal cycle is surprisingly similar throughout the year (Fig. 3). Semi-log graphs allow us to examine the relative variation among tides during months when the absolute densities of bacteria were different. Thus, the relative tidal variation was as great in January as in September (Fig. 3). The actual rates of changes in abundance (and chlorinity) did vary significantly throughout the year (see Tables 4 and 5 which are explained below).

We also observed tidal fluctuations in the number of bacteria attached to particles (Table 1). Attached bacteria were more abundant at low tide than at high tide. Nearly all the variation in this bacterial population was caused by the number of particles. The number of bacteria per particle did not vary significantly, but there were more particles at low tide than at high tide (Table 1). The proportion of total bacterial abundance attached to particles was approximately $1.8 \%$, which did not vary significantly over the tidal cycle.

For the remainder of our discussion on Great Sippewissett we will use the term 'bacterial abundance' even though the data are based only on the number of unattached bacteria. The error in using this simplification is $<2 \%$.

\section{Conservative and non-conservative tidal fluctuation in bacterial abundance}

Bacterial abundance fluctuated with the tides apparently because abundance was high in marsh water which mixed with Buzzards Bay water that contained fewer bacteria than the marsh. In order to examine whether bacterial abundance changed conservatively or non-conservatively, we examined the correlation between bacterial abundance and the conservative

Table 1. Particle-bound bacteria suspended in Great Sippewissett Salt Marsh during tidal cycles in June and August.

\begin{tabular}{|c|c|c|c|c|c|c|c|}
\hline Month & Time & Tide & $\begin{array}{c}\text { Unattached } \\
\text { bacteria } \\
\left(10^{6} \text { cells }\right. \\
\left.\mathrm{ml}^{-1}\right)\end{array}$ & $\begin{array}{c}\text { Particles } \\
\left(\begin{array}{c}10^{4} \text { particles } \\
\left.\mathrm{ml}^{-1}\right)\end{array}\right.\end{array}$ & $\begin{array}{l}\text { Bacteria } \\
\text { per } \\
\text { particle }\end{array}$ & $\begin{array}{c}\text { Attached } \\
\text { bacteria } \\
\left(10^{6} \text { cells }\right. \\
\left.\mathrm{ml}^{-1}\right)\end{array}$ & $\begin{array}{c}\% \text { particle- } \\
\text { bound } \\
\text { bacteria }\end{array}$ \\
\hline Jun & 0800 & \multirow[t]{2}{*}{ Low } & 1.5 & 0.43 & 2.8 & 0.038 & 2.5 \\
\hline \multirow{6}{*}{1980} & 1000 & & 1.4 & 0.43 & 4.3 & 0.019 & 1.3 \\
\hline & 1200 & \multirow{3}{*}{ High } & 0.86 & 0.25 & 3.9 & 0.0085 & 0.97 \\
\hline & 1400 & & 0.72 & 0.22 & 3.7 & 0.0083 & 1.2 \\
\hline & 1600 & & 0.98 & 0.16 & 3.2 & 0.0052 & 0.53 \\
\hline & \multirow[t]{2}{*}{1800} & \multirow[t]{2}{*}{ Low } & 1.0 & 0.38 & 3.0 & 0.012 & 1.2 \\
\hline & & & & & & & $\bar{x}=1.3$ \\
\hline \multirow{7}{*}{$\begin{array}{l}\text { Aug } \\
1979\end{array}$} & 0600 & Low & 2.6 & 1.1 & 7.4 & 0.081 & 3.9 \\
\hline & 1000 & \multirow{4}{*}{ High } & 1.1 & 0.49 & 5.6 & 0.028 & 2.6 \\
\hline & 1200 & & 0.98 & 0.57 & 5.1 & 0.029 & 2.9 \\
\hline & 1400 & & 1.4 & 0.62 & 4.9 & 0.031 & 2.1 \\
\hline & 1600 & & 1.8 & 0.88 & 3.5 & 0.031 & 1.7 \\
\hline & \multirow[t]{2}{*}{1800} & \multirow[t]{2}{*}{ Low } & 2.4 & 0.85 & 6.7 & 0.052 & 2.2 \\
\hline & & & & & & & $\bar{x}=2.6$ \\
\hline
\end{tabular}


tracer, chlorinity. With the exception of July, there was a significant, negative linear correlation $(p<0.01)$ between abundance and chlorinity (Table 2 ). The cor-

Table 2. Correlation between bacterial abundance and chlorinity during 2 consecutive tides in Great Sippewissett Salt Marsh

\begin{tabular}{|lcc|}
\hline Month & $\mathrm{r}^{*}$ & $\mathrm{~N}^{*}$ \\
\hline Jan & -0.90 & 26 \\
Feb & -0.91 & 26 \\
Mar & -0.73 & 26 \\
Apr & -0.92 & 25 \\
May & -0.73 & 26 \\
Jun & -0.68 & 26 \\
Jul & -0.14 & 23 \\
Aug & -0.78 & 25 \\
Sep & -0.90 & 26 \\
Oct & -0.70 & 26 \\
Nov & -0.72 & 25 \\
\multicolumn{3}{|c|}{} \\
With the exception of July, all linear correlation coeffi- \\
cients (r) are statistically significant (p < 0.01 ) \\
N = number of samples analyzed. The data from the 2 \\
tides were combined and analyzed together \\
\hline
\end{tabular}

relation coefficients $(\mathrm{r})$ ranged from -0.68 in June to -0.92 in April (Table 2). This analysis indicates that, as a first approximation, the bacterial populations appeared to mix conservatively, and the tidal fluctuation in bacterial abundance was the result of physical processes that also changed chlorinity.

However, when the graphs of bacterial abundance vs. chlorinity are examined, it becomes clear that the relation between bacterial abundance and chlorinity is more complex than indicated by the high linear correlation coefficients. We noticed 3 patterns in the graphs of bacterial abundance vs. chlorinity. First, in graphs of data from January and February, there is a negative linear relation between abundance and chlorinity (see Fig. 4 for data from January), which is consistent with the high correlation coefficients for these months (Table 2). However, a second pattern is evident in data from every other month but July. In graphs of data from these months, there is a curvilinear relation between bacterial abundance and chlorinity. The data from August and October are plotted in Fig. 4. Bacterial abundance was higher at the intermediate chlorinities than predicted from a straight line connecting bacte-
Fig. 4. Relation between bacterial abundance and chlorinity during 2 consecutive tidal cycles in Great Sippewissett Salt Marsh during Jan, Aug and Oct. Correlation coefficients ( $\mathrm{r}$ ) were $-0.90,-0.78$, and -0.70 for Jan, Aug and Oct, respectively. These correlations are all statistically significant $(p<0.01)$
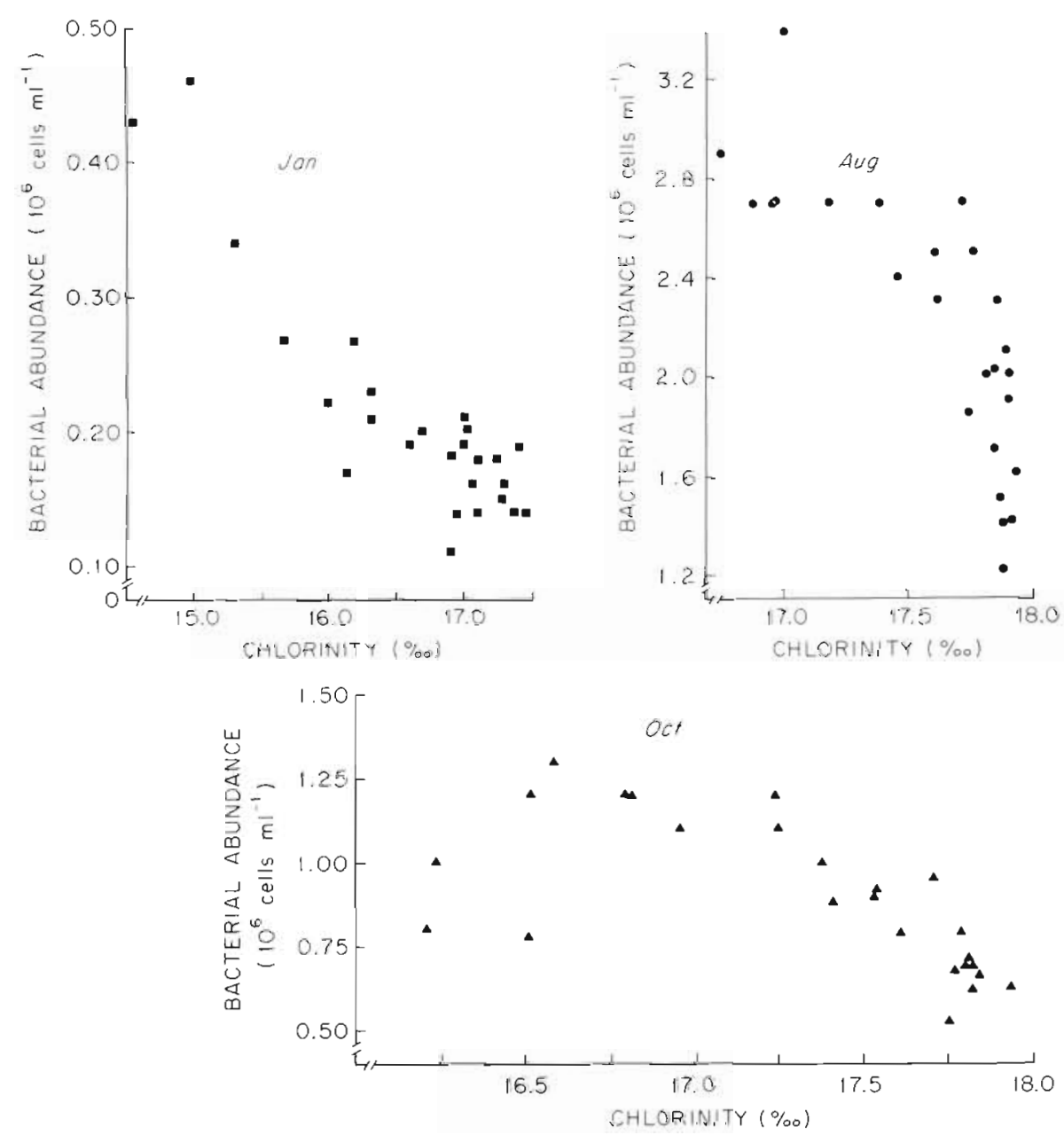
rial abundance at the lowest and highest chlorinity. The third pattern was noted in July only. In July there was no clear relation between bacterial abundance and chlorinity. The correlation coefficient for data from July is not significant ( $r=-0.14 ; \mathrm{p}>0.05$ ).

The nonlinear plots of bacterial abundance vs. chlorinity cannot be taken as evidence for non-conservative mixing because several water masses with different bacterial abundances and chlorinities seem to have been in the marsh during low tide, as discussed thoroughly below. Boyle et al. (1974) demonstrated that the patchy distribution of a constituent in an estuary will result in nonlinear plots of concentration versus chlorinity even if the constituent mixes conservatively.

As an alternative to plotting abundance vs. chlorinity, we determined how much variation in abundance and chlorinity could be explained by a simple exponential model. We reasoned that if conservative mixing was more important than biological factors in causing tidal variation in abundance, then the exponential model should describe well the variation in both abundance and chlorinity.

Each tide was divided into periods during which bacterial abundance either decreased or increased regularly. Only periods with a minimum of four samples were tallied in Tables 3 (ebbing tides) and 4 (flooding tides); most of the periods had greater than 6 samples. We then calculated first-order rate constants for changes in bacterial abundance and chlorinity by calculating the slope of ln (bacterial abundance or chlorinity) vs. time with a regression analysis.

The simple first-order model explained $>85 \%$ of the variation in both bacterial abundance and chlorinity, except for very slow $\left(<0.01 \mathrm{~h}^{-1}\right)$ changes or steadystate periods (Tables 3 and 4; Fig. 3). A large proportion ( $241 \mathrm{~h}$ out of a total sampling period of $286 \mathrm{~h}$ or $85 \%$ ) of the tidal cycles fit the exponential model. A small number of time periods ( $15 \%$ of total) could not be examined because of an inadequate number of samples.

The excellent fit of the exponential model for both chlorinity and bacterial abundance suggests that most of the tidal variation in bacterial abundance was due to nonbiological factors that influenced the concentration of both chloride ions and bacteria. The one dimensional models that describe the distribution of material over time and space as water masses mix are exponential functions (Officer, 1976). More complex models that include both biological and physical processes would predict that a simple exponential function would fit only poorly changes in bacterial abundance over a tidal cycle. Unfortunately, the rate constants for bacterial abundance and chlorinity cannot be compared directly because these constants reflect mixing rates and initial values of abundance and chlorinity in marsh water masses. A detailed study of the spatial distribution of these water masses would be necessary to interpret the rate constants unambiguously.

We hypothesize that the nonlinear relation between bacterial abundance and chlorinity was caused by variation in the ratio of bacterial abundance to chlorinity in isolated patches of water in the marsh. According to Boyle et al. (1974), this patchiness would result in a nonlinear relation between abundance and chlorinity as the water masses mixed. The mixing itself appeared to have been conservative and probably occurred in the main channel where several creeks join upstream from our sampling station (Fig. 1).

\section{Patchy distribution of bacteria within the marsh}

In order to determine if the bacterial populations and water masses were patchy in the marsh, we measured bacterial abundance, temperature and salinity at several sites during slack low tide in July 1980. The locations of these sites are indicated on Fig. 1 and the salinity of each site is the data point for the graph of bacterial abundance vs. temperature (Fig. 5).

The spatial distribution of water temperature and salinity demonstrates that the water in the marsh was not homogeneous. Water temperature and salinity varied greatly from site to site (Fig. 5). Warm water $\left(>25^{\circ} \mathrm{C}\right)$ was generally saltier (Fig. 5) than the cool water sampled furthest from the channel (Fig. 1). If the marsh were simply a source of bacteria, we expected to

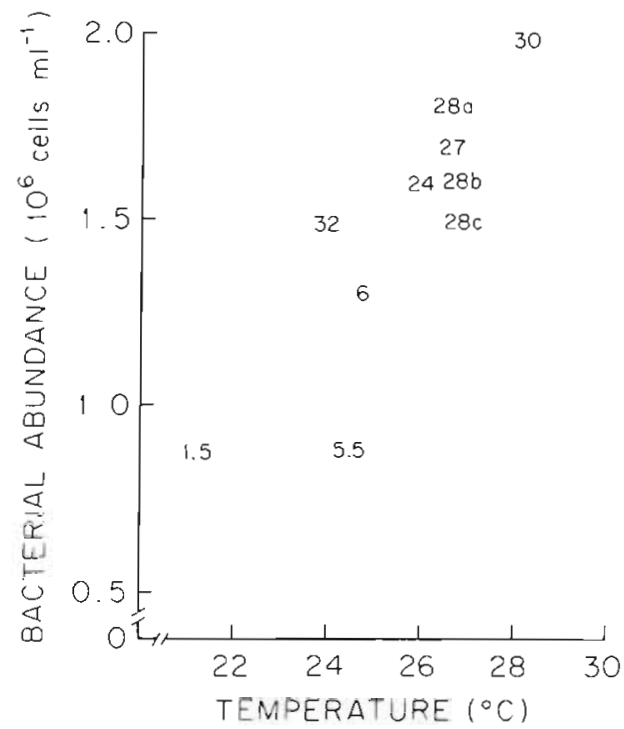

Fig. 5. Bacterial abundance, temperature and salinity along a transect at low tide in July 1980 in Great Sippewissett Salt Marsh. Numerals on graph are salinities $(\%)$ at the corresponding abundance and temperature. See Fig. 1 for location of each sample as indicated by salinity 
Table 3. First-order rate constants $\left(\mathrm{h}^{-1}\right)$ for the increase in bacterial abundance and decrease of chlorinity in Great Sippewissett Salt Marsh during ebbing tides

\begin{tabular}{|c|c|c|c|c|c|c|c|c|}
\hline \multirow[b]{2}{*}{ Month } & \multirow{2}{*}{$\begin{array}{l}\text { Time } \\
\text { period }\end{array}$} & \multicolumn{3}{|c|}{ Increase in bacteria } & \multicolumn{3}{|c|}{ Decrease in chlorinity } & \multirow[b]{2}{*}{$\mathrm{N}^{*}$} \\
\hline & & Rate & Error & $r^{2}$ & Rate & Error & $r^{2}$ & \\
\hline \multirow[t]{3}{*}{$\operatorname{Jan}$} & $1800-2100$ & 0.14 & 0.023 & 0.95 & -0.0010 & 0.00055 & 0.63 & 4 \\
\hline & $2200-0300$ & 0.13 & 0.0080 & 0.99 & -0.018 & 0.0019 & 0.96 & 6 \\
\hline & $0800-1500$ & 0.072 & 0.0073 & 0.94 & -0.011 & 0.0016 & 0.89 & 8 \\
\hline \multirow[t]{2}{*}{ Feb } & $2100-0100$ & 0.34 & 0.077 & 0.87 & -0.064 & 0.0081 & 0.95 & 5 \\
\hline & $0900-1400$ & 0.20 & 0.028 & 0.93 & -0.043 & 0.0075 & 0.99 & 6 \\
\hline \multirow[t]{2}{*}{ Mar } & $2400-0600$ & 0.014 & 0.012 & 0.21 & -0.016 & 0.0024 & 0.90 & 7 \\
\hline & $1100-1900$ & 0.058 & 0.013 & 0.75 & -0.016 & 0.0025 & 0.86 & 9 \\
\hline \multirow[t]{2}{*}{ Apr } & $1900-0400$ & 0.14 & 0.0056 & 0.99 & -0.013 & 0.0013 & 0.92 & 10 \\
\hline & $0700-1300$ & 0.14 & 0.035 & 0.76 & -0.0083 & 0.0020 & 0.77 & 7 \\
\hline \multirow[t]{2}{*}{ May } & $1800-0500$ & 0.067 & 0.0077 & 0.89 & -0.012 & 0.0019 & 0.80 & 11 \\
\hline & $0900-1600$ & 0.087 & 0.014 & 0.87 & -0.0091 & 0.0010 & 0.92 & 8 \\
\hline \multirow[t]{2}{*}{ Jun } & $1400-2200$ & 0.11 & 0.027 & 0.72 & -0.012 & 0.00083 & 0.97 & 9 \\
\hline & $2300-0700$ & 0.085 & 0.019 & 0.77 & -0.084 & 0.0025 & 0.66 & 8 \\
\hline Jul & $0600-1000$ & 0.15 & 0.029 & 0.89 & -0.027 & 0.0039 & 0.94 & 5 \\
\hline \multirow[t]{3}{*}{ Aug } & $0100-0500$ & 0.069 & 0.023 & 0.75 & -0.011 & 0.00026 & 0.99 & 5 \\
\hline & $0900-1300$ & 0.10 & 0.025 & 0.89 & -0.00074 & 0.00055 & 0.47 & 4 \\
\hline & $1300-1700$ & 0.084 & 0.018 & 0.88 & -0.013 & 0.0019 & 0.93 & 5 \\
\hline \multirow[t]{2}{*}{ Sep } & $2300-0300$ & 0.14 & 0.042 & 0.80 & -0.015 & 0.0011 & 0.98 & 5 \\
\hline & $0900-1500$ & 0.12 & 0.011 & 0.96 & -0.011 & 0.0017 & 0.90 & 7 \\
\hline \multirow[t]{2}{*}{ Oct } & $1800-0300$ & 0.077 & 0.0082 & 0.92 & -0.0085 & 0.00085 & 0.93 & 10 \\
\hline & $0800-1500$ & 0.090 & 0.0298 & 0.60 & -0.0010 & 0.0014 & 0.90 & 8 \\
\hline \multirow[t]{2}{*}{ Nov } & $1800-0100$ & 0.034 & 0.0065 & 0.82 & -0.012 & 0.0016 & 0.91 & 8 \\
\hline & $0800-1400$ & 0.054 & 0.020 & 0.59 & -0.015 & 0.0015 & 0.96 & 7 \\
\hline \multicolumn{9}{|c|}{$\begin{array}{l}\text { - First-order rates were calculated from the graphs of ln (bacterial abundance or chlorinity) vs. time. Data from Jan, Apr and } \\
\text { Sep are graphed in Fig. } 3 \\
\mathrm{~N}=\text { number of samples taken hourly during indicated time period. Total amount of time covered by the model can be } \\
\text { calculated by summing all time periods indicated in this table with the periods during flooding tide given in Table } 3 \text {. Time } \\
\text { examined during consecutive tides was } 26 \mathrm{~h} \text {. Usually, the model covers }>80 \% \text { of the } 26 \text { h examined }\end{array}$} \\
\hline
\end{tabular}

Table 4. First-order rate constants $\left(\mathrm{h}^{-1}\right)$ for the decrease in bacterial abundance and increase in chlorinity in Great Sippewissett Salt Marsh during flooding tides

\begin{tabular}{|c|c|c|c|c|c|c|c|c|}
\hline \multirow[b]{2}{*}{ Month } & \multirow{2}{*}{$\begin{array}{l}\text { Time } \\
\text { period }\end{array}$} & \multicolumn{3}{|c|}{ Decrease in bacteria } & \multicolumn{3}{|c|}{ Increase in chlorinity } & \multirow[b]{2}{*}{$N=$} \\
\hline & & Rate & Error & $r^{2}$ & Rate & Error & $r^{2}$ & \\
\hline Jan & $1400-1700$ & -0.52 & 0.11 & 0.92 & 0.047 & 0.019 & 0.76 & 4 \\
\hline Feb & $0200-0500$ & -0.46 & 0.089 & 0.93 & 0.11 & 0.026 & 0.90 & 4 \\
\hline Mar & $0700-1000$ & -0.23 & 0.021 & 0.98 & 0.043 & 0.0096 & 0.91 & 4 \\
\hline Apr & $1622-1900$ & -0.42 & 0.068 & 0.95 & 0.047 & 0.014 & 0.85 & 4 \\
\hline May & $0500-0800$ & -0.31 & 0.075 & 0.89 & 0.037 & 0.021 & 0.60 & 4 \\
\hline Jul & 0200-0600 & -0.18 & 0.014 & 0.98 & 0.0019 & 0.0031 & 0.11 & 5 \\
\hline Aug & $\begin{array}{l}1800-2400 \\
0500-0900\end{array}$ & $\begin{array}{l}-0.096 \\
-0.24\end{array}$ & $\begin{array}{l}0.0663 \\
0.043\end{array}$ & $\begin{array}{l}0.98 \\
0.91\end{array}$ & $\begin{array}{l}0.0011 \\
0.016\end{array}$ & $\begin{array}{l}0.00065 \\
0.0062\end{array}$ & $\begin{array}{l}0.38 \\
0.69\end{array}$ & $\begin{array}{l}7 \\
5\end{array}$ \\
\hline Sep & $\begin{array}{l}1400-1700 \\
0300-0800\end{array}$ & $\begin{array}{l}-0.091 \\
-0.22\end{array}$ & $\begin{array}{l}0.022 \\
0.031\end{array}$ & $\begin{array}{l}0.90 \\
0.93\end{array}$ & $\begin{array}{l}0.026 \\
0.015\end{array}$ & $\begin{array}{l}0.0079 \\
0.0050\end{array}$ & $\begin{array}{l}0.84 \\
0.68\end{array}$ & $\begin{array}{l}4 \\
6\end{array}$ \\
\hline Nov & $\begin{array}{l}1400-1700 \\
0100-0700\end{array}$ & $\begin{array}{l}-0.13 \\
-0.05\end{array}$ & $\begin{array}{l}0.033 \\
0.015\end{array}$ & $\begin{array}{l}0.88 \\
0.69\end{array}$ & $\begin{array}{l}0.024 \\
0.017\end{array}$ & $\begin{array}{l}0.0013 \\
0.0056\end{array}$ & $\begin{array}{l}0.64 \\
0.65\end{array}$ & $\begin{array}{l}4 \\
7\end{array}$ \\
\hline $\begin{array}{l}\text { - First-c } \\
\text { are gI } \\
\text {.- } \mathrm{N}=1 \\
\text { calcul } \\
\text { exami }\end{array}$ & $\begin{array}{l}\text { es were calcul } \\
\text { n Fig. } 3 \\
\text { of samples tal } \\
\text { summing all } \\
\text { ing consecuti }\end{array}$ & $\begin{array}{l}\text { an graph } \\
\text { rily duri } \\
\text { riods ind } \\
\text { was } 26\end{array}$ & $\begin{array}{l}\text { (bacter } \\
\text { licated } \\
\text { in this } \\
\text { ually, th }\end{array}$ & $\begin{array}{l}\text { ndanc } \\
\text { riod. } \\
\text { ith th }\end{array}$ & $\begin{array}{l}\text { lorinity) } \\
\text { amount } \\
\text { ods durir }\end{array}$ & $\begin{array}{l}\text { ime. Data } \\
\text { e covere } \\
\text { bing tide } \\
6 \text { h exam }\end{array}$ & $\begin{array}{l}\text { Jan, A } \\
\text { the mo } \\
\text { in Ta }\end{array}$ & $\begin{array}{l}\text { Sep } \\
\text { n be } \\
\text { Time }\end{array}$ \\
\hline
\end{tabular}


aged $0.17 \mathrm{~h}^{-1}$ and was virtually identical in 1979 and 1980 (Table 5). Growth of bay bacteria in filtered bay water was slow $\left(0.01 \mathrm{~h}^{-1}\right)$ but marsh bacteria in the same water grew relatively rapidly with a specific growth rate of $0.05 \mathrm{~h}^{-1}$ (Table 5). Marsh bacteria grew faster in Buzzards Bay water than we expected, perhaps because of DOC in the marsh water added with the marsh bacteria. The semilog plots of abundance vs. time were concave in 1979 (Fig. 6) but less so in 1980 (see Kirchman et al., 1982 for graphs of data from 1980). Kirchman et al. (1982) suggested that the concave plots were due to the presence of non-dividing cells.

The specific growth rate of bacteria in marsh water was fast enough to account for the average difference (approximately a factor of 4 ; Fig. 3 ) in bacterial abundance between low and high tides in August. Given a specific growth rate of $0.17 \mathrm{~h}^{-1}$ water must remain in the marsh for approximately $8 \mathrm{~h}\left(\ln 4 \div 0.17 \mathrm{~h}^{-1}\right)$ undiluted by bay water in order to explain the 4 -fold difference in abundance. Eight hours is close to the time required for water to ebb from the marsh. Only a very small portion of the flooding tide need remain in the marsh for $8 \mathrm{~h}$ in order for our hypothesis to be correct. In fact, the water volume remaining in the marsh at slack low tide is $<10 \%$ of the flooding tide. Thus, the difference in bacterial abundance between low and high tide can be accounted for by bacterial growth in a water mass that remains in the marsh at least as long as the ebbing tide.

\section{Contribution of bacteria to total particulate carbon}

We estimated how much of total particulate organic carbon (POC) suspended in the channel could be attributed to bacteria. Bacteria contributed significantly $(15 \%)$ to total POC in summer but not in winter $(<2 \%)$. The concentration of POC fluctuated during the year between 200 and $1,000 \mu \mathrm{g} \mathrm{Cl}^{-1}$ in the marsh (Fig. 7a). We estimate that bacterial biomass was at most $3 \mu \mathrm{g} \mathrm{C}^{-1}$ in winter when the number of bacteria was low (Fig. 7b). Bacterial biomass was as much as $15 \%$ of POC levels in August when the number of bacteria was high and bacterial biomass was about $60 \mu \mathrm{g} \mathrm{Cl}^{-1}$. In August, there was no significant difference in bacterial cell size in samples from high tide $\left(0.18 \pm 0.05 \mu \mathrm{m}^{3}\right)$ and low tide $\left(0.14 \pm 0.03 \mu \mathrm{m}^{3}\right)$.

We noticed an interesting pattern in the ratio of bacterial abundance to POC concentrations (Fig. 7C). This ratio is significantly higher at low tide, which is predominately marsh water, than at high tide which is predominately bay water $(p<0.025$; Wilcoxon's signed-ranks test). There could not have been a direct, causal relation between POC and bacteria, since the proportion of attached bacteria was small (Table 1).
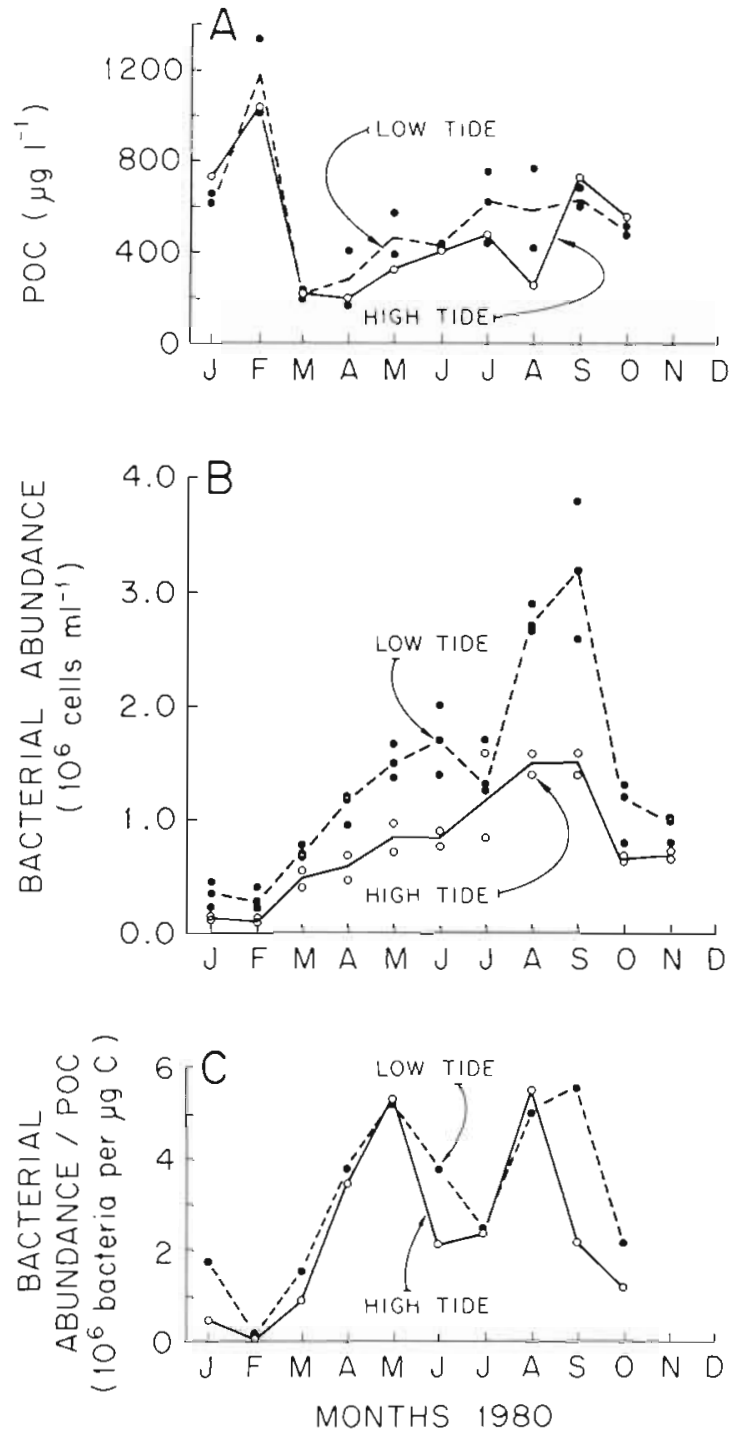

Fig. 7. Particulate organic carbon (POC) concentrations (A), bacterial abundance $(B)$, and ratio of abundance to $P O C$ concentrations (C) at consecutive low and high tides during 1980 in Great Sippewissett Marsh

However, POC levels may covary with DOC, which is utilized by unattached bacteria. The high ratio of bacteria to POC in marsh water may indicate that organic compounds in the marsh are less refractory and thus support greater bacterial growth compared with bay water.

\section{Seasonal variation in bacterial abundance}

In the channel of Great Sippewissett, bacterial abundance varied seasonally by a factor of approximately 9.5 at low tide and 7.5 at high tide (Fig. $7 b$ ). Minimum bacterial abundance occurred in January for both high and low tides. It is important to note that the 
maximum at low tide was in September when abundance was $3.8 \times 10^{6}$ cells $\mathrm{ml}^{-1}$. The seasonal maximum in bacterial abundance coincided with the seasonal maximum in sulfate reduction (Howarth and Teal, 1979) and in the export of reduced sulfur compounds out of the marsh (Peterson et al., 1982). In contrast, water temperature and aerobic respiration in surface sediments were highest in August (Howarth and Teal, 1979). Maximum bacterial abundance occurred in September, probably because marsh plants began to senesce in late August, releasing organic compounds that supported bacterial growth (Howarth and Teal, 1979). Energy and nutrients from marsh plants appear to drive, indirectly or directly, sulfate reduction in marsh sediments and bacterial abundance in marsh streams. Unlike low tides, during high tide bacteria were as abundant in July as in September (Fig. 7b). Since high tide samples were almost entirely bay water, these data suggest that bacterial abundance in the bay did not depend on the organic compounds released by marsh plants.

\section{Tidal exchange of bacteria between Great Sippewissett and Buzzards Bay}

The influence of salt marshes on adjacent coastal waters has been evaluated by examining the net flux of materials flowing into or out of a marsh. This analysis was applied to the transport of bacteria in the Great Sippewissett Marsh. Clearly, each day the marsh imported and exported a large number of particles. However, it was difficult to determine if in fact there was net export significantly different from zero. Although the export of bacteria out of the marsh was greater than the import of bacteria into the marsh in 16 out of 22 tidal cycles, only for 7 of these tides was the difference greater than $10 \%$, which is the approximate uncertainty in counting bacteria (Table 6).

The lack of a large net export of bacteria seems to contradict the large differences observed in bacterial abundance between high and low tides. However, the volume of water containing the high abundance was relatively small, and thus the export term was not as large as one might expect (see Fig. 8 for data from August on water and bacteria fluxes). In fact, changes in the hourly flux of bacteria were almost totally determined by hydrology as the water flux varied by over an order of magnitude; bacterial abundance varied only 2-fold in August (Fig. 8). Furthermore, bacterial abundance did not decrease instantaneously to the low value indicative of bay water when water stopped ebbing and started flooding the marsh; the flooding tide during its first hours pushed back ('imported') into the marsh water masses with relatively high bacterial abundance and chlorinity (Fig. 2; Fig. 8).
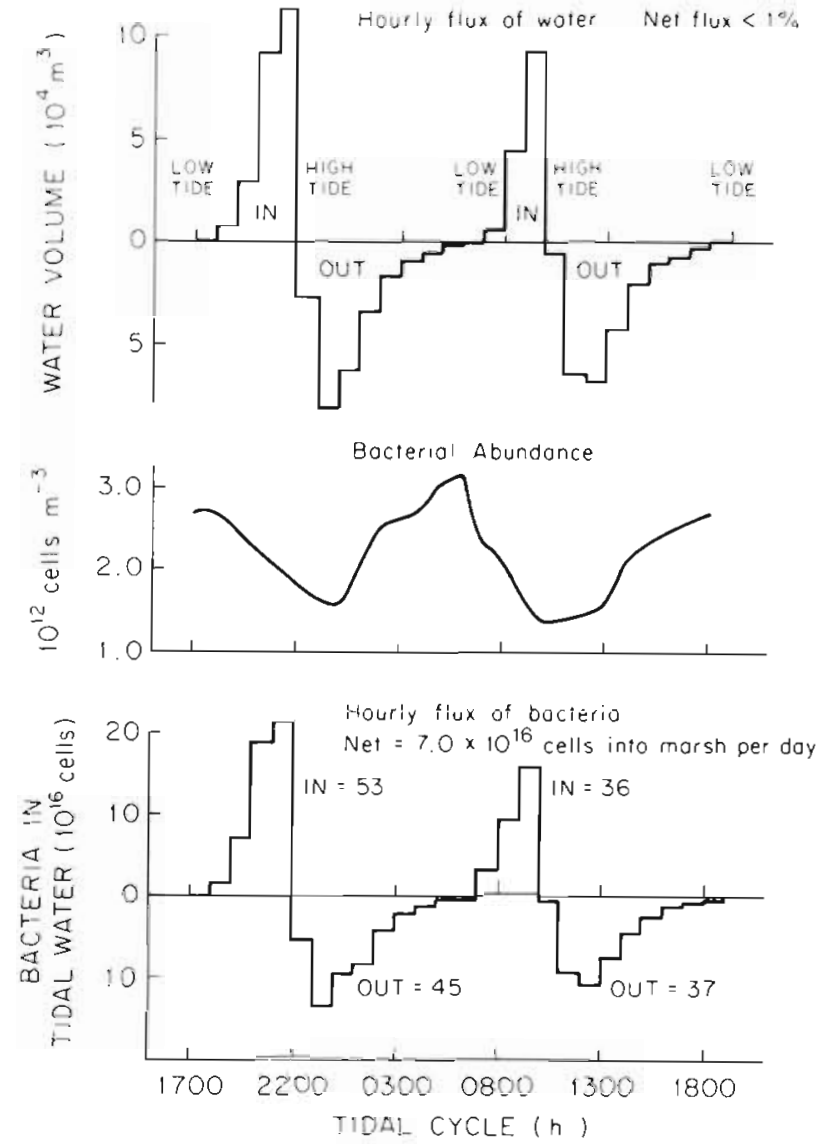

Fig. 8. Flux of water and bacteria into and from Great Sippewissett Marsh during Aug 1980. Samples taken every hour, on the hour

The negligible net export is not due to errors in the tidal water balance. The transport of water and bacteria reported here is not corrected for the slight difference in flooding and ebbing volumes due to fresh groundwater flow through the marsh. Our calculations assume that the flooding and ebbing total volume required to achieve an identical low tide height are equal. The fresh water flows have been calculated, but adjustment for fresh water throughout would change the tidal water balance by less than $1 \%$, and thus would have no measurable effect on the bacteria budget (Peterson et al, unpubl.).

\section{DISCUSSION}

The yearly variation in bacterial abundance in Great Sippewissett was probably determined by the supply of organic compounds from marsh grasses, the major primary producers in the marsh (Pomeroy et al., 1981). The large, absolute tidal variation in bacterial abundance observed in summer but not in winter follows the seasonal differences in the absolute magnitude of 
bacterial abundance. Large tidal variation occurred when bacterial abundance was high. However, on a logarithmic scale the tidal variation in bacterial abundance was roughly constant during the year. During all seasons abundance was relatively high at low tide and low at high tide. We hypothesize that the high bacterial abundance at low tide is the result of bacterial growth in nutrient-rich water masses isolated in the marsh. The nutrients probably originate from the Spartina rhizosphere or leakage from above-ground production. After growth in the nutrient-rich water, the now bacteria-rich water mixes rapidly and conservatively with Buzzards Bay water that contains relatively few bacteria. Conservative mixing appears to explain the logarithmic change in abundance that we observed in the main channel of the marsh.

Our explanation for the tidal variation in bacterial abundance emphasizes the importance of bacterial growth. This explanation is most applicable in Great Sippewissett to tidal cycles in summer, since data on bacterial growth rates and the spatial distribution of bacteria within the marsh are available from this sea- son. In winter, particularly January and February, processes other than growth are possibly important in contributing to the spatial and temporal variation in bacterial abundance observed in Great Sippewissett. January and February were exceptional, since there was no curvilinear relation between abundance and chlorinity, which was observed in every other month but July. One likely process contributing to the variation in bacterial abundance in the marsh water column is the release of bacteria from sediments. In fact, since the density of bacteria in sediments is approximately 1,000-fold higher than the bacterial density in the water column (Hobbie, 1979), the release of even a small proportion of the sediment bacterial population would have an impact on the water-column population.

However, several aspects of the spatial and temporal variation in bacterial abundance cannot be explained by the hypothesis that the release of bacteria from sediments to the water column is a significant process. In particular, low salinity water sampled farthest from the mouth of the channel had relatively low bacterial

Table 6. Transport of bacteria in Great Sippewissett Marsh

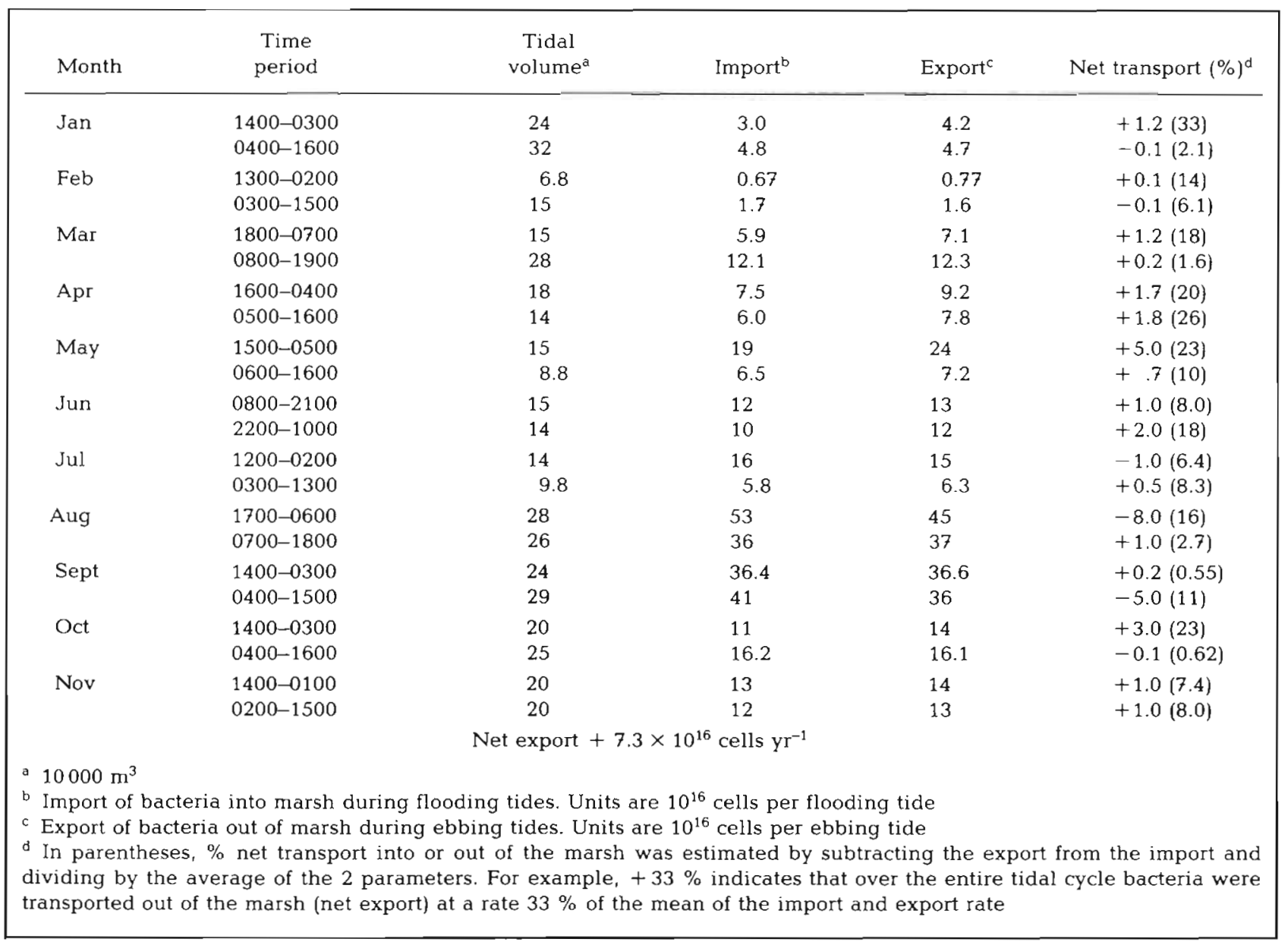


abundance (Fig. 5). This suggests that ground water percolating through the sediments does not contribute significantly to the variation in the planktonic bacterial population. In addition, Rublee et al. (1983) found that high salinity water did not remove bacteria from marsh sediments. Most of the low salinity/bacteriapoor water sampled during the survey at low tide never reached our channel sampling station and must have mixed with relatively high-salinity water. Nevertheless, several samples taken at the channel station each month had relatively low bacterial abundance and low chlorinity. In fact, the sample with the lowest chlorinity had fewer bacteria than samples with intermediate chlorinity in every month but January, February and July (Fig. 4). We suspect that the release by sediments of bacteria to the water column is random and is not the dominant process in determining the spatial and temporal variation in abundance that was observed in Great Sippewissett.

We evaluated the contribution of bacteria to the carbon cycle of the Great Sippewissett Marsh. Our data suggest that bacteria may be a large component of total POC in August when bacterial abundance is relatively high. However, bacteria do not appear to degrade a significant fraction of primary production in the marsh, nor do bacteria contribute substantially to the carbon required by the large mussel population in Great Sippewissett. These conclusions are based on our estimates of total bacterial production in the marsh. Data from August were chosen for these calculations because bacterial growth rates were measured in this month.

Bacterial production in the water column in August was estimated by multiplying the specific growth rate $\left(\mathrm{h}^{-1}\right)$ by the total bacterial biomass in the marsh $(\mathrm{g} \mathrm{C}$ marsh $^{-1}$ ). The specific growth rate in each of the hourly samples was estimated by regressing the growth rates presented in Table 5 against chlorinity $\left(\mu=-0.103\right.$ [chlorinity] $\left.-1.86 ; \mathrm{n}=4 ; \mathrm{r}^{2}=0.93\right)$. The total number of bacteria in the marsh was estimated from the flux of cells into or out of the marsh (Fig. 8). The number of bacteria left in the residual water that does not leave the marsh after slack low tide was added to the bacterial numbers in the flooding tide. The volume of this residual water is approximately $3.4 \times 10^{4} \mathrm{~m}^{3}$. Total bacterial production in the water column of the entire marsh over a tidal cycle was then calculated by summing the estimates for each hourly sample.

Total bacterial production in the marsh is about $8.6 \mathrm{~kg} \mathrm{C} \mathrm{d}^{-1}$ in August, according to the calculations outlined above. Net primary production in the marsh is about $500 \mathrm{~kg} \mathrm{C} \mathrm{d}^{-1}$ during August, based on the rate $\left(4.0 \mathrm{~g} \mathrm{~m}^{-2} \mathrm{~d}^{-1}\right)$ taken from Valiela et al. (1976), the area of marsh covered by marsh grasses $(3.03 \times$
$10^{5} \mathrm{~m}^{2}$ ), and assuming that these plants are $40 \%$ carbon. If bacteria respire $50 \%$ of the carbon taken up (Payne and Wiebe, 1978), then the calculated rates of bacterial production suggest that $<5 \%$ of primary production is processed by bacteria in marsh streams. Bacterial growth in marsh streams could have a large impact (turnover of $50 \% \mathrm{~d}^{-1}$ ) on DOC leached from marsh grasses (Gallager et al., 1976; Turner, 1978) only if the proportion of primary production leached is $<5 \%$. The bacteria may process a significant fraction of phytoplankton production, although this primary production is relatively small compared with rootplant production (Pomeroy et al., 1981).

Wright et al. (1982) demonstrated that the mussel Geukensia demissa can filter bacteria in marsh water with an efficiency of $30 \%$. Jordan and Valiela (1982) found that this mussel in Great Sippewissett Marsh is capable of filtering a volume of water in excess of the tidal volume during each tidal cycle in summer. However, the estimated bacterial production is not large enough to supply a significant portion of the carbon needed for mussel production as estimated by Jordan and Valiela (1982). In Great Sippewissett, mussels utilize $570 \mathrm{~kg} \mathrm{~N} \mathrm{yr}^{-1}$ for growth, gametes and byssal threads. This is $2,900 \mathrm{~kg} \mathrm{C} \mathrm{yr}^{-1}$ if we assume a C:N ratio of $5: 1$ (Jordon and Valiela, 1982). If mussels utilize that $2,900 \mathrm{~kg} \mathrm{C}$ mostly during 3 mo in summer, the daily consumption of carbon is $32 \mathrm{~kg} \mathrm{C} \mathrm{d}^{-1}$. The total bacterial production of $8.6 \mathrm{~kg} \mathrm{C} \mathrm{d}^{-1}$ could supply $<10 \%$ of mussel carbon production, assuming mussels filter out bacteria with $30 \%$ efficiency (Wright et al., 1982).

Based on the work of Jordon and Valiela (1982) and Wright et al. (1982), it seems likely that mussels as well as other filter-feeders in the marsh have a large impact on the bacterial population in marsh streams. If grazing by mussels were important, one could argue that the bacteria would have to grow even faster than the rates we have measured in order to account for the difference in bacterial abundance between low and high tide. However, the mussels are not uniformly distributed with depth or horizontally, and are only submerged for half a day (Jordon and Valiela, 1982). Thus, bacteria may escape predation by mussels when the tide ebbs and water levels drop.

In summary, on the ecosystem level the impact of the bacterial population in the marsh streams appears to be minimal with the possible exception of the impact of bacteria on DOC released by the marsh. Bacterial production appears to be small compared to total primary production of the marsh. Although bacteria may contribute significantly to total POC levels in summer, bacterial production alone does not appear to be great enough to support the large mussel population found in Great Sippewissett. Finally, the 
export of bacteria from the entire marsh to Buzzards Bay was negligible.

The data reported in this paper are more interesting and have more implications for examining the control of bacterial abundance than for illuminating directly the role of bacteria in estuaries. The spatial and temporal variation in bacterial abundance we observed in Great Sippewissett was large compared with the small variation usually observed in coastal waters (e.g. Ducklow and Kirchman, 1983). Grazing is thought to balance bacterial production, which may explain why bacterial abundance is relatively constant in coastal waters (Azam et al., 1983). In contrast, physical mixing in estuaries may increase bacterial abundance and bacterial growth rates, and thus the bacterial population may change faster than the planktonic bacteriovores can respond. Therefore, in estuaries bacterial production may become uncoupled from grazing, which results in large variations in bacterial abundance, such as observed in Great Sippewissett.

Acknowledgements. Several individuals, too numerous to mention, collected most of the samples, and we are grateful for their help. Melissa Lakich, who counted most of the bacteria, made this study possible; she and W. J. Wiebe commented on the manuscript; we appreciate their criticisms. We also thank Ralph Mitchell for his support of this research. The project was supported by NSF DEB 81-04701 awarded to the Ecosystems Center and by NSF predoctoral grant DEB79-20909 awarded to D. K. who was also supported by NOAA. Sea Grant NA81AAA-D-00085 awarded to Ralph Mitchell.

\section{LITERATURE CITED}

Azam, F., Fenchel, T., Field, J. G., Gray, J. S., Meyer-Reil, L.-A., Thingstad, F. (1983). The ecological role of water column microbes in the sea. Mar. Ecol. Prog. Ser. 10: $257-263$

Boyle, E., Collier, R., Dengler, A. T., Edmond, J. M., Ng, A. C., Stallard, R. F. (1974). On the chemical mass-balance in estuaries. Geochim. cosmochim. Acta 38: 1719-1728

Ducklow, H. W. (1983). Production and fate of bacteria in the oceans. Bioscience 33: 494-501

Ducklow, H., Kirchman, D. (1983). Bacterial dynamics and distribution during a spring diatom bloom in the Hudson River Plume. J. Plankton Res. 5: 333-555

Gallagher, J. L., Pfeiffer, W. J., Pomeroy, L. R. (1976). Leaching and microbial utilization of dissolved organic carbon from leaves of Spartina altemiflora. Estuar. coast. mar. Sci. 4: $467-471$

Hobbie, J. E. (1979). Activity and bacterial biomass. Arch. Hydrobiol. Beih. 12: 59-63

Hobbie, J. H., Daley, R. J., Jasper, S. (1977). Use of Nuclepore filters for counting bacteria by epifluorescence microscopy. Appl. environ. Microbiol. 33: 1225-1228
Howarth, R. W., Teal, J. M. (1979). Sulfate reduction in a New England salt marsh. Limnol. Oceanogr. 24: 999-1013

Jordon, T. E., Valiela, I. (1982). A nitrogen budget of the ribbed mussel, Geukensia clemissa, and its significance in nitrogen flow in a New England salt marsh. Limnol. Oceanogr. 27: 75-90

Kirchman, D., Mitchell, R. (1982). Contribution of particlebound bacteria to microheterotrophic activity in five coastal ponds and two marshes. Appl environ. Microbiol 43: 200-209

Kirchman, D., Ducklow, H. W., Mitchell, R. (1982). Estimates of bacterial production and growth rates based on changes in biomass and uptake rates. Appl. environ. Microbiol. 44: $1296-1307$

Officer, C. B. (1976). Physical oceanography of estuaries and associated coastal waters. John Wiley and Sons, New York

Palumbo, A. V., Ferguson, R. L. (1978). Distribution of suspended bacteria in the Newport River estuary, North Carolina. Estuar. coast. mar. Sci. 7: 521-529

Payne, W. J., Wiebe, W. J. (1978). Growth yield and efficiency in chemosynthetic microorganisms. A. Rev. Microbiol. 32: $155-183$

Peterson, B. J., Steudler, P. A., Howarth, R. W., Freidlander, A. I., Juers, D., Bowles, F. P. (1982). Tidal export of reduced sulfur from a salt marsh ecosystem. In: Hallberg, R. O. (ed.) Proceedings of the 5th Int. Symp. Environ. Biogeochem. Ecol. Bull. (Stockholm) 35: 153-165

Pomeroy, L. R., Darley, W. M., Dunn, E. L., Gallagher, J. L., Haines, E. B., Whitney, D. M. (1981). Primary production. In: Pomeroy, L. R., Wiegert, R. G. (ed.) The ecology of a salt marsh. Springer-Verlag, New York

Rublee, P. A., Merkel, S. M., Faust, M. A. (1983). The transport of bacteria in the sediments of a temperate marsh. Estuar coast. Shelf Sci. 16:501-509

Turner, R. E. (1978). Community plankton respiration in a salt marsh estuary and the importance of macrophytic leachates. Limnol. Oceanogr. 23: 442-451

Valiela, I., Teal, J. M. (1979). The nitrogen budget of a salt marsh ecosystem. Nature, Lond. 280: 652-656

Valiela, I., Teal, J. M., Persson, N. Y. (1976). Production and dynamics of experimentally enriched salt marsh vegetation: below ground biomass. Limnol. Oceanogr. 21: 245-252

Watson, S. W., Novitsky, T. J., Quinby, H. L., Valois, F. W. (1977). Determination of bacterial numbers and biomass in the marine environment. Appl. environ. Microbiol. 33: 940-946

Wilson, C. A., Stevenson, L. H. (1980). The dynamics of the bacterial population associated with a salt marsh. J. exp. mar. Biol. Ecol. 48: 123-135

Wright, R. T., Coffin, R. B. (1983). Planktonic bacteria in estuaries and coastal waters of N. Massachusetts: spatial and temporal distribution. Mar. Ecol. Prog. Ser. 11: 205-216

Wright, R. T., Coffin, R. B., Ersing, C. P., Pearson, D. (1982). Field and laboratory measurements of bivalve filtration of natural marine bacterioplankton. Limnol. Oceanogr. 27: 91-98

Wright, R. T., Coffin, R. B. (1984). Measuring microheterotrophic grazing of marine bacterioplankton with differential filtration and incubation. Microb. Ecol. 10: 137-149 